\title{
RECENSION \\ LA EMPRESA y EL DERECHO \\ (Carlos Urenda Zegers)
}

\section{Vladimir Rubilar Rivera Profesor de Derecho Constitucional Escuela de Derecho Universidad Católica del Norte}

La Empresa y el Derecho ${ }^{1}$, obra del abogado Carlos Urenda Zegers - quien ha sido profesor de Derecho Económico y de Derecho Civil en la Facultad de Ciencias Jurídicas y Sociales de la Universidad Católica -, de evidente interés en el ámbito jurídico, como asimismo, en otras esferas del quehacer nacional, especialmente en el medio empresarial. Esta afirmación tiene su fundamento en el tratamiento que realiza en su libro de diversos aspectos de carácter constitucional, de legislación civil y de materias de indole económica que aborda el autor.

Tiene el mérito indiscutible de constituirse en una invitación destinada a desarrollar en profundidad, temas que requieren este tratamiento, pues se carece de estudios sistematizados, al menos en el nivel nacional.

La drástica reorientación de la economía en Chile, a partir del año 1973, dió lugar al advenimiento de la economía social de mercado, abriendo en la actualidad, un amplio cauce a la investigación de las múltiples facetas que presenta una economía cuya influencia en el mundo contemporáneo pocos discuten.

Como lo señala el autor "al revés de una política económica simplemente liberal del pasado, dentro de una política social de mercado deben existir instrumentos que la promuevan y aceleren sus efectos positivos; y, paralelamente, instrumentos que la protejan de los efectos negativos que pueda producir la libertad económica.

Antes se confiaba sólo en un poder superior, en una mano invisible que regulaba el proceso, sin ninguna interferencia de la autoridad". En esta óptica, contratos conocidos internacionalmente como de franquicias (franchise o franchising) regalías o licencias o el contrato de factoring, en la legislación comercial moderna, son por una parte de indudable interés, y por otra, su aplicación práctica es cada vez mas frecuente, requiriendose con urgencia de literatura jurídica, destinada a satisfacer una realidad insoslayable en las relaciones comerciales existentes en nuestro país. 
Por el contrato de franquicias, regalías o licencias, una persona que es dueña de una marca, de un procedimiento, de una patente, de un know-how o conocimiento, otorga a otra la autorización para usar dicha propiedad intelectual, obligándose ésta a pagar por ello una regalía. Este contrato tiene un interés local e internacional en cuanto a que el dueño puede autorizar a otro para que use su propiedad intelectual o sus conocimientos, marcas o patentes, ya sea dentro o fuera del país.

En cuanto al contrato de factoring consiste en la convención entre una empresa denominada "cliente" y otra firma especializada llamada "factor", con el objeto de que esta última realice un conjunto de operaciones propias de aquella, para la contabilización, facturación, documentación, financiamiento y cobro de los créditos que emanen de las ventas y prestaciones de las empresas mercantiles o industriales de sus clientes.

El éxito de este contrato en otras latitudes, amerita su ànálisis en este país. Ciertamente, sobre esta convención y otras, que caracterizan el moderno mundo de los negocios, no son desconocidos trabajos en nuestro medio, como igualmente, no puede de cirse que no existan análisis sobre los mismos; pero sí puede afirmarse que éstos, además de ser escasos carecen de un tratamiento sistemático, que los haga accesibles al público. La obra del profesor Urenda es un paso hacia la reflexión en estas materiás.

Por otra parte, el autor como era natural en una obra destinada a un público amplio no ha podido sustraerse a la necesidad de precisar los principios que proclama la Constitución Política de 1980, destacando la declaración constitucional que expresa: "El ejercicio de la soberanía reconoce como limitación el respeto a los derechos esenciales que emanan de la naturaleza humana". Observa que además de la garantía constitucional al derecho de propiedad y a la propiedad, existen en la Carta Política contempladas con rango constitucional otras garantías, "que en conjunto constituyen el reconocimiento de la empresa libre o privada y la consagración del sistema económico capitalịsta". Destaca lo dispuesto en el inciso 20 № 21 del artículo 19 de la Constitución en cuanto dispone que "el Estado y sus organismos podrán desarrollar actividades empresariales o participar en ella sólo si una ley de quorum calificado los autoriza. En tal caso, esas actividades estarán sometidas a la legislación común aplicables a las particulares, sin perjuicio de las excepciones que por motivos justificados establezca la ley, la que deberá ser, asimismo, de quórum calificado (mayoría absoluta de los diputados y senadores en ejercicio).

Lo expuesto viene a reafirmar la consagración del sistema económico actualmente vigente en Chile.

A este respecto parece pertinente consignar a propósito de esta reseña, referida a algunos aspectos de la obra del profesor Urenda Zegers, lo que tan acertadamente sostiene el destacado profesor de Derecho Constitucional y Ciencia Política de la Universidad Católica José Luis Cea Egaña, en su ensayo "Constitución Plena", al señalar que la Constitución Política de 1980 "no se contrae a las reglas del sistema político" 2 . "Antes bien, en ella han sido fijadas las bases en que se fundará la convivencia pública y privada en los aspectos social, económico y político" ${ }^{3}$. "Es una Constitución nueva porque res-

2 Tratado de la Constitución de 1980. Características Generales. Garantías Constitucionales. José Luis Cea Egaña. pág. 39 . Editorial Jurídica de Chile. 
ponde a un conjunto de valores que no es el mismo contenido en la Carta precedente. En esto - agrega - no hay crítica a la Constitución anterior, venerable por varios conceptos, sino una apreciación positiva de la que nos rige, en el sentido de que quienes asumieron' la tarea de crearla comprendieron lo frágil que sería restaurar instituciones vencidas por los hechos, siendo imperativo dictar otro Estatuto acorde con los cambios vividos". 4

Con agudeza, el destacado constitucionalista señala que la neutralidad que caracteriza a la Constitución de 1925 en el aspecto económico, abrió una brecha imposible de bloquear, permitiendo "la interpretación y aplicación fraudulenta de la Constitución a traves de resquicios exegéticos" ${ }^{5}$, siendo una de las causas de la crisis de la institucionalidad hace dos décadas. Para los efectos de esta recensión, es importante destacar "el marco jurídico básico en que se desenvuelve la gestión económica de los individuos, los grupos intermedios y el Estado para el bien común, con igualdad de oportunidades reconocida a los sujetos de la economía" 6 . El profesor Cea Egaña, defiende el Orden Político Económico como "el conjunto de principios y normas jurídicas que organizan la económía de un país y facultan a la autoridad para regularla en armonía con los valores de la sociedad nacional formulados en la Constitución" $"$.

Es a la luz que arroja la perspectiva o basamentos constitucionales citados, en que se cimenta la obra del profesor Urenda Zegers en comento, situando una serie de temas referidos a la regulación del comercio, la legislación financiera y laboral en dicha perspectiva.

Los estudiantes de derecho bien pueden encontrar en sus páginas, elementos muy valiosos para pensar en trabajos de investigación en materias muy actuales, sobre las que poco se ha profundizado o reactualizado.

\footnotetext{
3 pág. 39 obra citada.

4. pág. 39 obra citada.

5 pág. 156 obra citada.

6. pág. 157 obra çitada.

7 pág. 158 obra citada.
} 